\title{
THE CONSTITUTIONAL PRINCIPLE OF SCIENTIFIC DEVELOPMENT BASED ON SOCIAL INTEREST AND THE PATENT LEGAL SYSTEM: THE CASE OF CHAGAS DISEASE
}

\author{
O PRINCÍPIO CONSTITUCIONAL DO DESENVOLVIMENTO CIENTÍFICO COM BASE \\ NO INTERESSE SOCIAL E O SISTEMA JURÍDICO DE PATENTES: O CASO DA \\ DOENCA DE CHAGAS
}

Marcos Vinício Chein Feres

Ph.D. in Economic Law from Universidade Federal de Minas Gerais (UFMG), Associate Professor at Universidade Federal de Juiz de Fora (UFJF), Research Scholar PQ 2, CNPq. (Bolsista de Produtividade do CNPq), Professor for the Master`s Course in Law and Innovation at the Law School of UFJF.

E-mail: mvchein@gmail.com

Lorena Abbas da Silva

Undergraduate Student at Universidade Federal de Juiz de Fora (UFJF); Scholarship from FAPEMIG. E-mail: lorenaabbas@tutanota.com

Alan Rossi Silva Master`s Degree Student in Law and Innovation at the Law School of Universidade Federal de Juiz de Fora (UFJF); Bachelor in Law from UFJF.

E-mail: alanrossi100@gmail.com

Recebido em: 20/04/2017 Aprovado em: 13/11/2017

\begin{abstract}
This research adopts a normative political institutional approach, which may empirically contest the constitutional principle of scientific development in accordance with social interest applied to the Brazilian patent legal system, considering the specificities of the case of Chagas disease. Firstly, the theoretical references "living lawfully" and "the struggle for recognition" will be structured as a point of departure for reconstructing the essence of legal methodology that is applied to the case of patent requests concerning Chagas disease. Secondly, a full description of the empirical methodology of analysis is presented, so as to justify every step of the methodological pathway and its implementation, which results in a critical analysis of the legal patent system. Finally, a critique of this system is elaborated, taking into account the analytical process of reasonable descriptive inference provided by the official data extracted from the Brazilian Institute of Industrial Property Rights and converted into cross-referenced tables.

Keywords: Empirical research. Scientific development. Social interest. Chagas disease. Law as identity.

RESUMO: Esta pesquisa adota uma abordagem político-normativa institucional, de sorte a empiricamente contestar o princípio constitucional do desenvolvimento científico baseado no interesse social aplicado ao sistema jurídico brasileiro de patentes, considerando as especificidades do caso da doença de Chagas. Em primeiro lugar, as referências teóricas, "viver plenamente a Lei" e "a luta pelo reconhecimento", são estruturadas como um único ponto de
\end{abstract}


partida para a reconstrução da essência da metodologia científica que pode ser aplicada ao caso de pedidos de patente relativos à doença de Chagas. Em segundo lugar, é apresentada uma descrição completa da metodologia empírica de análise, de modo a justificar o caminho metodológico para a implementação das regras de inferências aplicadas ao caso dos depósitos de patentes, o que resulta numa análise crítica do sistema jurídico de patentes. Por fim, elabora-se uma crítica a este sistema, levando em conta o processo analítico de uma razoável inferência descritiva extraída dos dados oficiais encontrados no Instituto Brasileiro de Direitos de Propriedade Industrial (INPI) e, assim, convertidos em referências cruzadas por meio de tabelas.

Palavras-Chave: Pesquisa empírica. Desenvolvimento científico. Interesse social. Doença de Chagas. Direito como identidade.

SUMMARY: Introduction; 1. Theoretical Reference; 2. Methodology; 3. Discussion of results; Conclusion; References.

\section{INTRODUCTION}

This research adopts a normative political institutional approach, which may empirically contest the effectiveness of the constitutional principle of scientific development in accordance with social interest applied to the Brazilian patent legal system, considering the specificities of the case of Chagas disease.

Neglected diseases negatively affect the lives of 1 billion people all over the world, while threatening the health of another million people. In this context, poor communities are seriously afflicted by those maladies. In fact, this demonstrates the failure to meet one relevant millennium development goal, that is, the access to health care and to essential medicines (OMS, 2010). Nowadays, those diseases occur mostly in tropical zones where precarious housing, lack of clean water and proper sewage, insect infestation and biological vectors of those illnesses contribute to the likelihood of infections (OMS, 2010).

According to Médecins Sans Frontières (2016), the problem of neglected diseases is related to the absence of economic interest on the part of private pharmaceutical industries in developing more effective drugs to treat endemic diseases, such as, malaria, Chagas disease, leishmaniasis and dengue fever. These are called neglected diseases, as there is no direct market interest in investing large sums of money to develop drugs, which may promote the diagnosis, prevention and/or treatment of these infirmities.

In this vein, though simple it may seem to verify the necessary enforcement of the constitutional principle of scientific development and social interest under which lies the patent legal system (CORREA, 2007, p. 93), there is not one single piece of empirical evidence which demonstrates that patents are, in fact, fostering innovation ${ }^{1}$ (scientific development), mainly, as far as the development and production of drugs for neglected diseases are concerned. Moreover, according to Feres and Silva (2017), most of the incentives to the pharmaceutical industries are more likely to be related to market opportunities rather than to public health care interests. This can be corroborated by the low number of drug approvals for the prevention and cure of neglected diseases in comparison with the high number of drug approvals for global diseases (PEDRIQUE et al., 2013). Médecins Sans Frontières (2016) reports that, in the last two decades, the pharmaceutical industries have failed to deliver therapeutic options for neglected diseases. This lack of interest for innovation coincides and contrasts with the blossoming of a historical

\footnotetext{
${ }^{1}$ Boldrin and Levine (2008) conducted a meta-study in which 24 academic papers were analyzed so as to verify if the strengthening of patent legal system would lead to better levels of innovation. They have come to a conclusion that those studies failed to find evidence that would sustain the empirical causal relationship between the increasing number of patents granted and better levels of innovation and productivity.
} 
period of intellectual property rights legislature. In this context, the political demand for strengthening patent rights derives from an outdated sector of the pharmaceutical industry ${ }^{2}$, whose investment in marketing strategies is two times more than the investment in basic research for the development of new drugs (GOLD et al., 2010).

This study focuses on verifying whether the existing legal acts concerning the patent legal system fulfill their constitutional duties (scientific development based on social interest), taking into consideration the socio-economic effects derived from the actual number of patent requests specifically destined for developing drugs for neglected diseases. As a matter of fact, it is crucial to evaluate how rights established in multilateral agreements, such as, Trade-Related Aspects of Intellectual Property Rights (TRIPS), have been distorted so as to serve the selfinterest of capitalist societies in which the most viable interpretation of a legal rule is the one that will promote profit to the detriment of social aims. So as to reinforce the main objective of intellectual property rights regulation, it is worth noting the guiding principle of intellectual property rights in article 7 of TRIPS Agreement,

The protection and enforcement of intellectual property rights should contribute to the promotion of technological innovation and to the transfer and dissemination of technology, to the mutual advantage of producers and users of technological knowledge and in a manner conducive to social and economic welfare, and to a balance of rights and obligations (WTO, 2017)

The Brazilian Constitution (BRASIL, 1988), as stated in article 5, XXIX, reiterates the same aspiration (BANKOWSKI, 2001), establishing the necessary intertwining of scientific development and social interest as a founding principle of the patent legal system.

The theoretical reference here applied consists of the idea of law as identity, complemented by Taylor's (1989) concept of identity and Bankowski's (2001) approach of living lawfully. Identity in law consists of a new line of legal reasoning for it encompasses the structural components of the theory of struggle for recognition, love, rights and esteem and turns them into methodological instruments for re-establishing a new rule of law under the risk of love. This tension between law and love, explored by Bankowski, summarizes an advanced level of methodological expertise in re-evaluating the nature of legal interpretation in contemporary societies. Here lies the encounter between the methodology of content analysis and the methodology of identity in law. No matter what type of data one is dealing with, the process of extracting specific data from a certain context and re-interpreting the data in the context of a new theoretical basis brings to the foreground new traits of significance, whose meaning might otherwise have not been obvious. So as to make the argument clearer, the act of interpreting the functioning of the patent legal system, such as the number of patent requests for products for diagnosis, prevention and treatment of Chagas disease, is elaborated following the rules of inference (EPSTEIN; KING, 2002). Identity in law overcomes the theoretical obstacles of living lawfully and integrity in law by elucidating how legal rules are transformed and turned into a new law by taking into account the context of their application. This implies the recognition of common moral ground, which includes different worldviews and ethical choices so as to assure the identity of human beings in a pluralistic society under the rule of law. The rule of law should be conceived as an institutional structure that establishes universal norms whose purpose is to inform, to analyze and to evaluate the complexity of a specific case.

\footnotetext{
${ }^{2}$ In spite of the statement above, there is also a more innovative and modern sector in the pharmaceutical industry. However, the patent legal system is designed to promote the outdated strategies of those who already have patents granted and a privileged position to influence intellectual property rights policies to the detriment of the interests of young and modern entrepreneurs as well as final consumers (BOLDRIN; LEVINE, 2013).
} 
This methodological approach proposes the reconstruction of a system of analytical concepts based on contemporary legal theory in order to collect data from the Brazilian Institute of Industrial Property Rights (INPI, in Portuguese), responsible for the registration of patent requests in Brazilian territory. Basically, the methodology here applied is conceived, taking into account, not only the relevance of interpreting factual and legal data, but also the nature of legal institutions and legal theory. Bearing in mind the institutional perspective developed in the virtuous circle of love, rights and esteem, an analytical system of concepts is prepared to infer descriptive facts from the data collected in the INPI. According to Epstein and King (2002), the very first goal of empirical research should be amassing data in such a way that others may execute the same procedure and achieve similar results. In this vein, its research goal is to collect data from the INPI database. According to Epstein and King (2002), the first purpose here is to explain thoroughly what procedure was followed to get the patent data which was necessary for deducing the inference during the discussion of the research results here achieved.

In this sense, before structuring the results of the analysis, the procedure of selecting, collecting and scrutinizing data, concerning the patent requests for drugs for neglected diseases, is described in detail. This research on neglected diseases requires a necessary investigation on the context of the occurrence of these maladies. Most of the literature on this topic presents a list of neglected diseases, which does not correspond to the different realities of each country. This can be certified by the comparison between the lists organized by World Health Organization (WHO, 2017) and the neglected diseases that affect the Brazilian population (ABC, 2010). For example, Malaria is not considered a neglected disease in the WHO list.

First of all, neglected diseases, such as, dengue fever, Chagas disease, leshimaniasis, and malaria, were selected for this study, considering the high epidemiological occurrences in different regions in Brazil, as well as the availability of statistical data systematized in official entities, such as, the role of the request - prevention, diagnosis or treatment -, the product type and the profile of the inventor available on the website of INPI (2017).

Chagas disease has proved to be one of the most endemic diseases in Brazilian territory (LINDOSO; LINDOSO, 2009, p. 247-253). After collecting the data on the INPI website (2017), the number of requests concerning Chagas disease reveals, at face value, a low degree of interest in developing new drugs, compared with three other maladies, dengue fever, malaria and leshimaniasis. These three infirmities have, respectively, 157, 86 and 65 requests on the INPI website (2017). Considering the data related to other neglected diseases on the website, it is easily verifiable that there are 33 requests for Chagas disease, 6 requests for Hansen's disease, but no requests were found for onchocerciasis and elephantiasis. It is important to point out that, among the eight diseases aforementioned, Chagas disease, malaria, leshimaniasis and dengue fever present patent requests, taking into account that these requests need to meet the following criteria of taxonomy, such as, prevention, diagnosis and treatment of the disease, as well as the information about the type of the product and the profile of the inventor. Therefore, Chagas disease is a neglected disease with enough data so as to fulfill the objectives of this research, i.e., evaluate the degree of effectiveness of the patent legal system regarding the search for scientific innovation combined with social interest.

The official website of the INPI (2017) was accessed in order to map out the patent system. Having collected the data, it was necessary to elaborate a critical methodological procedure of analysis, establishing a mechanism of inference which enabled the scrutiny of the logic behind the patent requests for pharmaceuticals concerning Chagas disease, relating this patent request to a certain pattern of behavior which might be a reflection, either negative or positive, of the implementation of the constitutional principle of scientific development interwoven with social interest. The methodological mechanism offered a viable possibility of interpreting the logic of the patent legal system, inferring whether the administrative decisions 
were made in accordance with market rationale and its mainstream or in accordance with fundamental constitutional rights.

Stemming from this approach, this paper is divided into three major parts. Firstly, the theoretical reference will be structured as a point of departure for reconstructing the essence of legal methodology that is applied to the case of patenting drugs for neglected diseases. Secondly, a full description of the empirical methodology of analysis will be presented so as to justify every step of the methodological pathway and its implementation, which result in a critical analysis of the patent legal system. Finally, a critique of this system will be elaborated, taking into account the analytical process of inferential deduction of official data extracted from the INPI.

\section{THEORETICAL REFERENCE}

The first step here before analyzing the suitability of patenting drugs for neglected diseases is to conceptualize the theory of law as identity ${ }^{3}$.

Honneth (1996, p. 176) distinctly affirms: "subjects mutually experience themselves to be loved in their individuality only insofar as they are not afraid to be alone", because their identity depends on the experience of love rooted in an open dialogue among human beings. It is important to understand that love is used here as a kind of umbrella term for all kinds of social solidarity, empathy and mutual fraternal feelings among human beings. Thus, love only exists in a relationship, regardless of the degree of sentiment a human being could develop in the experience of love. Basically, love cannot exist in a vacuum, in isolation, but in a context of interaction. In fact, according to Honneth (1996, p. 176) "the experience of love, whatever historical form it takes, represents the innermost core of all forms of life that qualify as "ethical"'. Honneth (1996) also demonstrates the function of love as well as the ability of human beings to develop their affective system in the construction of human identity and self-confidence. Taylor seems to follow the same reasoning, affirming: "our lives exist also in the space of questions, which only a coherent narrative can answer. In order to have a sense of who we are, we have to have a notion of how we have become" (TAYLOR, 1989, p. 47). This narrative, which is conceived in the relationship with others, in a dialogical process, is paramount in understanding the formation of human identity and in experiencing love in all aspects of a human life.

Taylor (1989) founded his theory on the axiom that morality incorporates, not only what is right to do, but also what is right to be. It is inconceivable to make qualitative distinctions of worth based, exclusively, on a guide to action. This qualitative distinction of worth, as proposed by Taylor (1989), requires a profound understanding of what kind of role righteousness plays as an essential component of the moral evaluation of a self. Thinking about the kind of life that is worth living is a relevant step towards the formation of a moral attitude of a self. Taylor's (1989) study of the making of modern identity serves to enlighten what is known as the moral dimension of a legal interpretive practice. In order to elaborate legal interpretive practice beyond the exclusive dimension of fit, it is essential to think about what kind of individual you want to be as well as what kind of community you intend to have (DWORKIN, 1986). However, this is possible only if individuals are capable of reflective thinking, which consists of pondering about what is right to do and what is right to be. The quest for this moral dimension necessitates a real commitment to always being reflective about the kind of human being that a personified community values. Here lies the beginning of a legal practice based on identity. Following this reasoning, living lawfully will represent the last piece of this legal puzzle.

Living lawfully, according to Bankowski (2001), needs a true commitment to what is righteous. In order to achieve this ideal, it is, first of all, paramount to understand the rules under

\footnotetext{
${ }^{3}$ Feres (2013) develops this theoretical reference for the first time in an article, elucidating that the idea of law as identity originates from the interconnection of Dworkin's (1986) perspective of law as integrity, Bankowski's (2001) theory of living lawfully and Taylor's (1989) idea of modern identity.
}

Revista de Direito Brasileira | São Paulo, SP | v. 20 | n. 8 | p. 81-103 |Mai./Ago. 2018 
which humans live; secondly, it is essential to pay attention to the story that is told, to the particularity of each case presented to the jurist; thirdly, it is fundamental to reconstruct the meaning of legislation through, what Bankowski (2001, p. 174-180) himself denominates, "parabolic reasoning"; finally, law and love will structure bridging institutions based on the possibility of going beyond a semantic interpretive legal perspective without disregarding the relevance of legality. A structural question arises: how can this theory be effectively applied in legal practice?

Parabolic reasoning is a methodological tool, which logically explains the underpinnings of Bankowski's theory. In spite of having been based on a Christian belief system, parabolic reasoning is easily conceived as an interpretive practice applied to Ancient Law. Bankowski (2001, p. 99-101) exemplifies this specific reasoning, taking as a model of interpretive practice, the parable of the Good Samaritan. He relates Jesus's explanation given to the lawyer when asked what the content of Ancient Law was and what "acting in a neighborly manner to people" meant. As a matter of fact, the lawyer wanted to put Jesus in a difficult position for he was suspected of disregarding Ancient Law. Nonetheless, Jesus responded to the lawyer showing a thorough understanding of the law as well as demonstrating the ability to interpret the law beyond a strictly semantic approach. Jesus reconstructs the meaning of "neighbor" by telling the story of the Good Samaritan. According to the proposed interpretation, acting in a neighborly manner signifies that you should leave your comfort zone so as to help someone in need. It means that the reason why help is granted is not because the other is vulnerable and wounded but it is because the helper grasps the true meaning of being at the same time autonomous and vulnerable in a risky society. According to Bankowski (2001, p. 99-101), the other is not the Jew fallen among thieves but the Samaritan who runs the risk of putting himself in a vulnerable situation by helping the other on a dangerous road, as the road from Jericho to Jerusalem was known.

Succinctly, parabolic reasoning can be constituted as a methodological instrument to execute critical reconstruction of legality by going beyond the law "within the context of the inside" (BANKOWSKI, 2001, p. 177). Honneth (1996, p. 178) also confirms this idea in his theory of struggle for recognition by affirming that social solidarity "is geared towards the possibility of symmetrical esteem among legally autonomous citizens". In order to achieve this kind of social solidarity, it is essential to allow substantive values to occupy a central role alongside love and legal rights in the construction of human identity (HONNETH, 1996, p. 179). The idea of human identity is truly interconnected with the notion of legality as a result of expressions of love in our society. The rule of law should be interpreted as a mechanism for promoting the self-realization of an individual in a pluralistic society where people will have different objectives, interests and purposes in life. From the perspective of living lawfully, it is essential to consider that human lives are interwoven and their common ground is the idea of sharing moral values as well as respecting diverse ethical choices. Producing drugs for neglected diseases on a large scale requires not only effective public policies but also a kind of interpretive practice, which goes beyond the semantic meaning of patent rights. Taking into account the vulnerability of the population affected by these diseases as part of an interpretive program concerning intellectual property rights represents a huge step towards a more inclusive legal application.

Identity in law (FERES, 2013) overcomes the theoretical obstacles of living lawfully and struggle for recognition by elucidating how legal rules are transformed and turned into a new law by taking into account the context of their application. Stemming from this institutional intertwining between the universal norms and the complexity of a particular case, it is possible to extract new forms of law application from the complexity of not only the presence of diverse requests involving patents for neglected diseases, but also the lack of patent requests for prevention, diagnosis and treatment of neglected diseases. 
Metaphorically, Dworkin (1986, p. 189-190) compares this aforementioned process with the chain novel, whereas Bankowski (2001) utilizes for the same purpose the idea of a soap opera with new episodes being added. Nevertheless, a valid metaphor for describing this idea of identity in law in a context of struggle for recognition is the remixing of different types of music. Although sampling without proper license is considered to be illegal by the lobby of the copyright music industry, it is a way of preserving the original source of a specific song, however, executed in a totally different manner. A good example is the Brazilian concept of "tecno-brega" which can take an entire original song, such as, "Crazy", from Gnarls Barkley, subsequently adding specific beats that will essentially transform the old song into a renewed expression of art which is more relevant to the social context in case. This new song produced by Brazilians maintains the source of the original one, nonetheless with fragmentary elements of locality and specificity. Thus, a new identity for a song originally produced by an American band is creatively and locally transformed. This sense of identity implies the possibility of creative reconstruction taking into consideration the interests, the needs and the prospects of a specific community. The quest for empirical fragments which complement the meaning of a legal rule can be compared to the quest for a specific beat that might change the sound of a song without discarding its original melody. In this sense, it is possible to see a strong similarity with parabolic reasoning and, above all, the possibility of formulating, in law, the differentiated unity, proposed by Bankowski (2001). The original song is re-contextualized, is not lost at all but, is indeed merged in a context of a new beat. Identity in law is this possibility of managing the essence of a legal rule in a new context of social inclusiveness (FERES, 2013). Each individual of the community can recognize himself in the process of applying legal rules to others. Here lies identity in law as a methodological concept, which includes every single member of the community in the mechanism of creative legal reconstruction.

\section{METHODOLOGY}

Basically, the methodology here applied is conceived, taking into account not only the relevance of interpreting factual and legal data but also the nature of legal institutions and legal theory. Considering the institutional perspective developed in the virtuous circle of love, rights and esteem, an analytical system of concepts is prepared to infer descriptive facts from the data collected in the INPI.

In this sense, before structuring the results of the analysis, it was paramount to describe the procedure of selecting, collecting and scrutinizing data concerning the patenting requests for four of the neglected diseases.

The official website of the INPI(2017) was accessed in order to, firstly, map out the patent system. Secondly, once the website had been scrutinized, the patent request database was revealed and extracted. So as to do this, it was necessary to click on the following links: "services", "trademark, patent, industrial design and software" and "continue". Subsequently, one is redirected by the website to a point where one can select "basic research for patents" and the search for the aforementioned neglected diseases is possible to execute. The type of web research utilized is the one called "basic research" which is carried out by selecting "keywords" which should appear in the "abstract" registered on the website, so as to visualize the largest possible number of registers concerning one specific neglected disease. This search procedure was carried out separately for each of the aforementioned neglected diseases.

According to Article 30 of the Brazilian Industrial Property Rights Act (Lei 9279/96) (BRASIL, 1996), the request ought to be published in Industrial Property Rights Journal after eighteen months of secrecy, counting from the date of the registration or from what is considered to be the oldest documented research. This study is based on the analysis of the publications of the requests between January $1^{\text {st }}, 2000$ and October $28^{\text {th }} 2015$. The publications on the INPI web- 
search platform are updated weekly in the Industrial Property Rights Journal. Journal number 2338, published on October $27^{\text {th }}, 2015$, was utilized as the parameter for the construction of the tables in this paper.

Considering the large amount of information to be systematized, this paper was specifically devoted to analyzing the number of patent requests per year for Chagas disease, the role of the patent requested, and the name of the institution interested in patenting these products. It is relevant to justify why Chagas disease was chosen among the other neglected diseases previously selected. First of all, the table of systematization of the patent request data collected on the website of the INPI (2017) revealed, at face value, a lower level of scientific interest concerning the specific case of Chagas disease. Secondly, as far as empirical research is concerned, it was appropriate to reduce the scope of the research so as to get more accurate results.

After reading all the archives, containing abstracts, full descriptive reports and patent claims to be granted, related to the patent requests available at the database on the INPI website (2017), it is possible to classify the role of the product to be patented, utilizing the following criteria, prevention, diagnosis and treatment. Stemming from Bankowski's idea of a tension between duty and aspiration (FERES, 2013), the patent requests from the database of the INPI website (2017) are subdivided into the categories of the registrations, i.e., prevention (aspiration to prevent the neglected disease from disseminating), diagnosis (aspiration to identify the disease through an appropriate scientific method) and treatment (aspiration to impede and cure the disease).

From the viewpoint of empirical research, there are methodological limitations as far as the data access is concerned. Due to this, it was not possible to verify whether the registration process and the payment of fees were effectuated in due course.

Furthermore, this research disregarded procedures in which more than one type of neglected diseases was mentioned in the abstract available on the website. In the case of two similar patent requests, it was only necessary to consider that a single difference in the request document was enough to distinguish one final proposal from another. While collecting the data, it was perceived that some of the registrations did not have any direct relationship with Chagas disease, as the product was not developed to prevent, diagnose or treat the disease, and, thus were ignored. As a result, this specific situation is classified as anomalous registration.

Once data was amassed, it was necessary to summarize it. In this context, the research conducted here was formatted in four specific tables. Most of the data collected was summarized in these tables so as to facilitate the visualization of the frequency of patent requests. The second table can be described as a consequence of crosstabulation where a large number of relevant data was selected to make it easier to perceive the descriptive inference.

Moreover, the possibility of managing the essence of a legal rule in a new context of social inclusiveness is the essence of this research as a theoretical point of departure. In evaluating the effectiveness of the constitutional principle of scientific development and social interest, such as, the idea of social, economic and scientific development in the application of intellectual property rights rules, the methodological mechanism, here applied, of analysis of patent requests to verify the actual effects of the Brazilian Industrial Property Rights Act (BRASIL, 1996) should be well-designed and thoroughly explained.

The final objective of this analysis is to reevaluate the legal act in a context of social inclusiveness. Identity in law requires a more critical analysis of patent requests so as to determine if there is an actual need for a change, not only in the legislative and administrative perspectives, but also in the realm of public policies. The institutional effect of love and identity in the construction of legal arguments assists the analysis of patent requests as a consequence of the application of the Industrial Property Rights Act (BRASIL, 1996) and the formulation of the descriptive inference derived from those numbers of requests and their particularities. 
From the data collected and systematized, it was not possible to conclude that the patented products were, actually, developed and commercialized by pharmaceutical industries. In this vein, the non-marketing of these products aggravates the nature of this endemic problem in Brazil and hampers the possibility of prevention and cure of these infirmities.

Although Boldrin and Levine (2013) ${ }^{4}$ identified the non-verifiable relationship between the rate of innovation and the number of patents granted in the United States, this research will use the number of patent requests to measure the effectiveness of the patent legal system, which ought to be grounded on the constitutional principle of scientific development and social interest. This can be justified, first of all, because one of the theoretical premises is that the nature of a private firm is to maximize their profits and, thus, the exclusivity granted by the patent legal system contributes to that sort of maximization. In spite of that, there are not sufficient requests even to raise substantial doubt as to the utilization of this indicator as a possible measurement of the ineffectiveness of the constitutional principle.

\section{DISCUSSION OF THE RESULTS}

Table 1 - Number of Patent Requests Registered per Year (Jan 2001 - Oct 2015)

\begin{tabular}{|c|c|c|c|c|c|}
\hline YEAR & Dengue & $\begin{array}{l}\text { Chagas } \\
\text { Disease }\end{array}$ & Leishmaniasis & Malaria & TOTAL/YEAR \\
\hline 2013 & 1 & 4 & 8 & 3 & 16 \\
\hline 2012 & 7 & 6 & 6 & 3 & 22 \\
\hline 2011 & 14 & 1 & 3 & 3 & 21 \\
\hline 2010 & 11 & 0 & 7 & 3 & 21 \\
\hline 2009 & 17 & 2 & 5 & 4 & 28 \\
\hline 2008 & 20 & 4 & 2 & 5 & 31 \\
\hline 2007 & 15 & 3 & 3 & 16 & 37 \\
\hline 2006 & 17 & 2 & 12 & 11 & 42 \\
\hline 2005 & 4 & 1 & 5 & 7 & 17 \\
\hline 2004 & 7 & 2 & 4 & 10 & 23 \\
\hline 2003 & 12 & 3 & 5 & 5 & 25 \\
\hline 2002 & 18 & 4 & 4 & 7 & 33 \\
\hline 2001 & 8 & 0 & 0 & 3 & 11 \\
\hline
\end{tabular}

\footnotetext{
${ }^{4}$ According to Boldrin and Levine (2013), in spite of the increasing number of granted patents and the strengthening of patent legislation in the United States, it is not possible to verify an equivalent rate of technological improvement, let alone corresponding levels of investment in research and development.
} 

2000
6
1
1
6
14

\section{TOTAL/}

Disease

157

33

65

86

341

Source: Data collected by the authors directly from INPI database, 2017.

Note: ( $\left.{ }^{1}\right)$ Exact date of data collection: 10/27/2015.

This first table lists all the patent requests, referring to dengue, Chagas disease, leishmaniasis and malaria, registered over a fourteen-year period on the INPI (2017) official website. One out of the four neglected diseases, Chagas disease, had the lowest level of request registrations during the period of analysis. During this time, only 33 patents for Chagas disease were requested. Moreover, dengue has approximately 4.75 times more requests than Chagas disease, which corroborates the hierarchy among different sorts of neglected diseases. In fact, it is right to state that some diseases are more neglected than others. Once this heterogeneity of requests is verified, the patent legal system must be reinterpreted in order to consider the complexity of each disease in its specific context, as required by the idea of living lawfully (BANKOWSKI, 2001). This table serves to demonstrate the relevance of conducting a more thorough analysis of the nature of requests related to Chagas disease submitted to the INPI, which will be depicted as shown in the tables 2, 3 and 4 .

Table 2 - Patent Requests Concerning Chagas Disease (Jan 2001 - Oct 2015)

\begin{tabular}{|c|c|c|c|c|c|c|}
\hline & $\begin{array}{c}\text { Number } \\
\text { of the } \\
\text { request }\end{array}$ & $\begin{array}{l}\text { Date of } \\
\text { the } \\
\text { request }\end{array}$ & Role & Product & Inventor & $\begin{array}{c}\text { Country } \\
\text { of } \\
\text { Origin }\end{array}$ \\
\hline 1 & $\begin{array}{c}\text { BR 10 } \\
2013 \\
0319279 \\
\text { A2 }\end{array}$ & $\begin{array}{c}12 / 12 / 201 \\
3\end{array}$ & $\begin{array}{c}\text { Treatme } \\
\text { nt }\end{array}$ & $\begin{array}{l}\text { Pharmaceutical } \\
\text { composition }\end{array}$ & $\begin{array}{c}\text { Universidad } \\
\text { e Estadual } \\
\text { Paulista } \\
\text { Júlio de } \\
\text { Mesquita } \\
\text { Filho } \\
\text { (BR/SP) / } \\
\text { Université } \\
\text { de Genève } \\
\text { (CH) }\end{array}$ & Brazil \\
\hline 2 & $\begin{array}{c}\text { BR } 10 \\
2013 \\
0280968 \\
\text { A2 }\end{array}$ & $\begin{array}{c}10 / 31 / 201 \\
3\end{array}$ & $\begin{array}{c}\text { Treatme } \\
\text { nt }\end{array}$ & $\begin{array}{l}\text { Pharmaceutical } \\
\text { composition }\end{array}$ & $\begin{array}{l}\text { Universidad } \\
\text { e Federal } \\
\text { Fluminense } \\
(\mathrm{BR} / \mathrm{RJ})\end{array}$ & Brazil \\
\hline
\end{tabular}




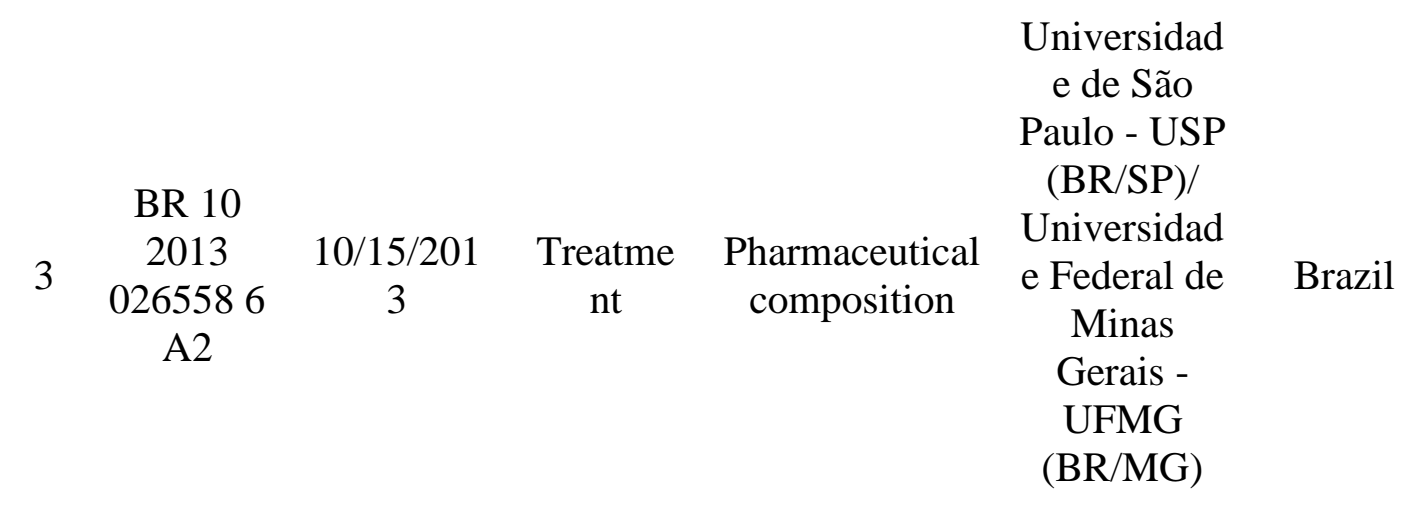

BR 10

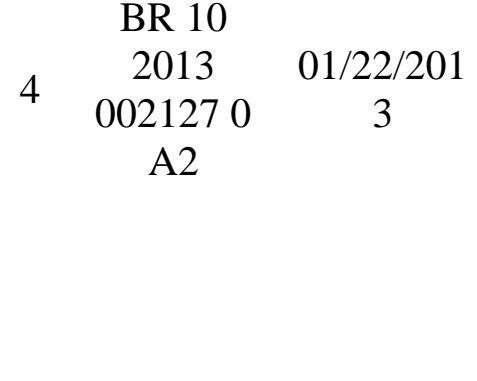

BR 10
$\begin{array}{ccc}5 & 2012 & 10 / 31 / 201 \\ 0279975 & 2\end{array}$
A2

$\begin{array}{cc}\begin{array}{c}\text { Treatme } \\ \text { nt }\end{array} & \begin{array}{c}\text { Pharmaceutical } \\ \text { composition }\end{array} \\ & \\ \text { Diagnosi } & \begin{array}{c}\text { Method and kit } \\ \text { for }\end{array} \\ & \begin{array}{c}\text { immunodiagno } \\ \text { sis }\end{array}\end{array}$

Universidad

e Federal da

Paraíba

(BR/PB)

Universidad

e Federal de

Minas

Gerais

(BR/MG) /

Fundação

de Amparo

à Pesquisa

do Estado

de Minas

Gerais -

FAPEMIG

(BR/MG)

Universidad

e Federal do

Rio de

Janeiro -

BR 10

$6 \begin{array}{ccccc}2012 & 07 / 31 / 201 & \text { Treatme } & \text { Pharmaceutical } \\ \text { composition }\end{array}$

A2
UFRJ

(BR/RJ) /

Universidad

e Federal de

Alagoas

(BR/AL)

Universidad

e Federal do

Rio Grande

do Norte

(BR/RN)
Brazil

Brazil

Brazil

Brazil 


\begin{tabular}{|c|c|c|c|c|c|c|}
\hline $8 *$ & $\begin{array}{c}\text { BR 10 } \\
2012 \\
0182149 \\
\text { A2 }\end{array}$ & $\begin{array}{c}06 / 21 / 201 \\
2\end{array}$ & $\mathrm{x}$ & $\begin{array}{l}\text { Machine for } \\
\text { cleaning the } \\
\text { açai seed. }\end{array}$ & $\begin{array}{c}\text { Fricontel } \\
\text { Comércio } \\
\text { de Aço } \\
\text { Inoxidável e } \\
\text { Refrigeraçã } \\
\text { o LTDA } \\
\text { (BR/PA) }\end{array}$ & Brazil \\
\hline 9 & $\begin{array}{c}\text { BR 10 } \\
2012 \\
0103036 \\
\text { A2 }\end{array}$ & $\begin{array}{c}05 / 02 / 201 \\
2\end{array}$ & $\begin{array}{l}\text { Preventi } \\
\quad \text { on }\end{array}$ & $\begin{array}{l}\text { Bacteria } \\
\text { For silencing } \\
\text { genes in } \\
\text { triatomines }\end{array}$ & $\begin{array}{c}\text { Universidad } \\
\text { e Federal do } \\
\text { Rio de } \\
\text { Janeiro } \\
(\mathrm{BR} / \mathrm{RJ})\end{array}$ & Brazil \\
\hline 10 & $\begin{array}{c}\text { BR 10 } \\
2012 \\
0018764 \\
\text { A8 }\end{array}$ & $\begin{array}{c}01 / 27 / 201 \\
2\end{array}$ & $\begin{array}{l}\text { Diagnosi } \\
\qquad \mathrm{s}\end{array}$ & $\begin{array}{l}\text { Recombinant } \\
\text { Trypanosoma } \\
\text { cruzi for } \\
\text { evaluating the } \\
\text { efficiency of } \\
\text { treatment or } \\
\text { vaccines. }\end{array}$ & $\begin{array}{c}\text { Universidad } \\
\text { e Federal de } \\
\text { Minas } \\
\text { Gerais - } \\
\text { UFMG } \\
\text { (MG)/ } \\
\text { Fundação } \\
\text { de Amparo } \\
\text { à Pesquisa } \\
\text { do Estado } \\
\text { de Minas } \\
\text { Gerais - } \\
\text { FAPEMIG } \\
\text { (MG) }\end{array}$ & Brazil \\
\hline 11 & $\begin{array}{c}\text { PI } \\
1103777 \\
-6 \text { A2 }\end{array}$ & $\begin{array}{c}08 / 19 / 201 \\
1\end{array}$ & $\begin{array}{c}\text { Treatme } \\
\text { nt }\end{array}$ & $\begin{array}{l}\text { Pharmaceutical } \\
\text { composition }\end{array}$ & $\begin{array}{c}\text { Universidad } \\
\text { e de São } \\
\text { Paulo - USP } \\
\text { (SP) / } \\
\text { Fundação } \\
\text { de Amparo } \\
\text { à Pesquisa } \\
\text { do Estado } \\
\text { de São } \\
\text { Paulo - } \\
\text { FAPESP } \\
\text { (SP) }\end{array}$ & Brazil \\
\hline
\end{tabular}




\begin{tabular}{|c|c|c|c|c|c|c|}
\hline 12 & $\begin{array}{c}\text { PI } \\
0904827 \\
-8 \text { A2 }\end{array}$ & $\begin{array}{c}11 / 06 / 200 \\
9\end{array}$ & $\begin{array}{l}\text { Preventi } \\
\text { on and } \\
\text { diagnosis }\end{array}$ & $\begin{array}{l}\text { Recombinant } \\
\text { Peptides for } \\
\text { diagnosis and } \\
\text { vaccines }\end{array}$ & $\begin{array}{c}\text { Universidad } \\
\text { e Federal de } \\
\text { Uberlândia } \\
\text { - UFU } \\
\text { (MG) / } \\
\text { Fundação } \\
\text { de Amparo } \\
\text { à Pesquisa } \\
\text { do Estado } \\
\text { de Minas } \\
\text { Gerais - } \\
\text { FAPEMIG } \\
\text { (MG) / } \\
\text { Imunoscan } \\
\text { Engenharia } \\
\text { Molecular } \\
\text { Ltda-Me } \\
\text { (MG) }\end{array}$ & Brazil \\
\hline 13 & $\begin{array}{c}\text { PI } \\
0903451 \\
-0 \text { A2 }\end{array}$ & $\begin{array}{c}08 / 27 / 200 \\
9\end{array}$ & $\begin{array}{c}\text { Treatme } \\
\text { nt }\end{array}$ & $\begin{array}{l}\text { Phamarceutical } \\
\text { compounds for } \\
\text { medicines }\end{array}$ & $\begin{array}{c}\text { Universidad } \\
\text { e Federal do } \\
\text { Piauí } \\
\text { (BR/PI) }\end{array}$ & Brazil \\
\hline 14 & $\begin{array}{c}\text { PI } \\
0805492 \\
-4 \mathrm{~A} 2\end{array}$ & $\begin{array}{c}12 / 02 / 200 \\
8\end{array}$ & $\begin{array}{c}\text { Treatme } \\
\text { nt }\end{array}$ & $\begin{array}{c}\text { Pharmaceutical } \\
\text { composition }\end{array}$ & $\begin{array}{c}\text { Fundação } \\
\text { de Amparo } \\
\text { à Pesquisa } \\
\text { do Estado } \\
\text { de São } \\
\text { Paulo - } \\
\text { FAPESP } \\
\text { (SP) / } \\
\text { Universidad } \\
\text { e de São } \\
\text { Paulo - USP } \\
\text { (SP) }\end{array}$ & Brazil \\
\hline 15 & $\begin{array}{c}\text { PI } \\
0805753 \\
-2 \mathrm{~A} 2\end{array}$ & $\begin{array}{c}10 / 31 / 200 \\
8\end{array}$ & $\begin{array}{l}\text { Preventi } \\
\text { on and } \\
\text { treatment }\end{array}$ & Vaccine & $\begin{array}{c}\text { Carlos de } \\
\text { Baeremaeck } \\
\text { er Barros } \\
\text { (UY) }\end{array}$ & $\begin{array}{c}\text { Argentin } \\
\mathrm{a}\end{array}$ \\
\hline 16 & $\begin{array}{c}\text { PI } \\
0806285 \\
-4 \text { A2 }\end{array}$ & $\begin{array}{c}01 / 15 / 200 \\
8\end{array}$ & $\begin{array}{l}\text { Preventi } \\
\quad \text { on }\end{array}$ & $\begin{array}{c}\text { Genetically } \\
\text { modified } \\
\text { antigens ASP- } \\
2\end{array}$ & $\begin{array}{c}\text { Universidad } \\
\text { e Federal de } \\
\text { Minas } \\
\text { Gerais - } \\
\text { UFMG } \\
\text { (MG) }\end{array}$ & Brazil \\
\hline
\end{tabular}




\begin{tabular}{|c|c|c|c|c|c|c|}
\hline 17 & $\begin{array}{c}\text { PI } \\
0801906 \\
-1 \text { A2 }\end{array}$ & $\begin{array}{c}01 / 15 / 200 \\
8\end{array}$ & $\begin{array}{l}\text { Preventi } \\
\text { on }\end{array}$ & $\begin{array}{l}\text { Genetically } \\
\text { modified } \\
\text { antigen TS }\end{array}$ & $\begin{array}{l}\text { Universidad } \\
\text { e Federal de } \\
\text { Minas } \\
\text { Gerais - } \\
\text { UFMG } \\
\text { (MG) }\end{array}$ & Brazil \\
\hline 18 & $\begin{array}{c}\text { PI } \\
0714722 \\
-8 \mathrm{~A} 2\end{array}$ & $\begin{array}{c}07 / 13 / 200 \\
7\end{array}$ & $\begin{array}{c}\text { Treatme } \\
\text { nt }\end{array}$ & $\begin{array}{l}\text { Pharmaceutical } \\
\text { compounds }\end{array}$ & $\begin{array}{c}\text { Amura } \\
\text { Therapeutic } \\
\text { s Limited } \\
\text { (GB) / John } \\
\text { Paul Watts } \\
\text { (GB) }\end{array}$ & $\begin{array}{l}\text { United } \\
\text { Kingdom }\end{array}$ \\
\hline 19 & $\begin{array}{c}\text { PI } \\
0700836 \\
-8 \mathrm{~A} 2\end{array}$ & $\begin{array}{c}03 / 20 / 200 \\
7\end{array}$ & $\begin{array}{c}\text { Preventi } \\
\text { on or } \\
\text { Treatme } \\
\text { nt }\end{array}$ & $\begin{array}{l}\text { Pharmaceutical } \\
\text { compounds }\end{array}$ & $\begin{array}{c}\text { Fundação } \\
\text { Oswaldo } \\
\text { Cruz - } \\
\text { FIOCRUZ } \\
\text { (RJ) }\end{array}$ & Brazil \\
\hline 20 & $\begin{array}{c}\text { PI } \\
0709560 \\
-0 \text { A2 }\end{array}$ & $\begin{array}{c}03 / 14 / 200 \\
7\end{array}$ & $\begin{array}{l}\text { Preventi } \\
\text { on and/or } \\
\text { treatment }\end{array}$ & Vaccine & $\begin{array}{l}\text { Vib Vzw } \\
\text { (BE) / } \\
\text { Universiteit } \\
\text { Gent (BE) }\end{array}$ & $\begin{array}{c}\text { Europea } \\
\text { n Patent } \\
\text { Organiza } \\
\text { tion }\end{array}$ \\
\hline 21 & $\begin{array}{c}\text { PI } \\
0603872 \\
-7 \mathrm{~A} 2\end{array}$ & $\begin{array}{c}08 / 24 / 200 \\
6\end{array}$ & $\begin{array}{l}\text { Diagnost } \\
\text { ic }\end{array}$ & $\begin{array}{l}\text { Method and } \\
\text { diagnostic kit } \\
\text { for measuring } \\
\text { treatment } \\
\text { efficacy }\end{array}$ & $\begin{array}{c}\text { Fundação } \\
\text { Universidad } \\
\text { e de Brasília } \\
\text { (DF) }\end{array}$ & Brazil \\
\hline 22 & $\begin{array}{c}\text { PI } \\
0603871 \\
-9 \text { A2 }\end{array}$ & $\begin{array}{c}08 / 24 / 200 \\
6\end{array}$ & $\begin{array}{c}\text { Treatme } \\
\text { nt }\end{array}$ & $\begin{array}{l}\text { Pharmaceutical } \\
\text { compositions }\end{array}$ & $\begin{array}{c}\text { Fundação } \\
\text { Universidad } \\
\text { e de Brasília } \\
\text { (DF) }\end{array}$ & Brazil \\
\hline 23 & $\begin{array}{c}\text { PI } \\
0502172 \\
-3 \mathrm{~A} 2\end{array}$ & $\begin{array}{c}06 / 13 / 200 \\
5\end{array}$ & $\begin{array}{c}\text { Treatme } \\
\text { nt }\end{array}$ & $\begin{array}{l}\text { Pharmaceutical } \\
\text { compositions }\end{array}$ & $\begin{array}{c}\text { Universidad } \\
\text { e Estadual } \\
\text { de } \\
\text { Campinas - } \\
\text { UNICAMP } \\
\text { (SP) / } \\
\text { Universidad } \\
\text { e de São } \\
\text { Paulo - USP } \\
\text { (SP) }\end{array}$ & Brazil \\
\hline
\end{tabular}




\begin{tabular}{|c|c|c|c|c|c|c|}
\hline 24 & $\begin{array}{c}\text { PI } \\
0417231 \\
-0 \text { A2 }\end{array}$ & $\begin{array}{c}12 / 06 / 200 \\
4\end{array}$ & $\begin{array}{l}\text { Diagnost } \\
\text { ic }\end{array}$ & $\begin{array}{l}\text { Bio-marks to } \\
\text { identify the } \\
\text { stages of } \\
\text { disease }\end{array}$ & $\begin{array}{c}\text { Mcgill } \\
\text { University } \\
\text { (CA) / } \\
\text { Vermillion, } \\
\text { Inc. (US) }\end{array}$ & $\begin{array}{l}\text { United } \\
\text { States }\end{array}$ \\
\hline 25 & $\begin{array}{c}\text { PI } \\
0401107 \\
-4 \text { A2 }\end{array}$ & $\begin{array}{c}04 / 13 / 200 \\
4\end{array}$ & $\begin{array}{l}\text { Preventi } \\
\text { on or } \\
\text { treatment }\end{array}$ & $\begin{array}{l}\text { Pharmaceutical } \\
\text { compound for } \\
\text { medicine }\end{array}$ & $\begin{array}{c}\text { Fundação } \\
\text { Oswaldo } \\
\text { Cruz - } \\
\text { FIOCRUZ } \\
\text { (BR) }\end{array}$ & Brazil \\
\hline 26 & $\begin{array}{c}\text { PI } \\
0310123 \\
-1 \text { A2 }\end{array}$ & $\begin{array}{c}12 / 04 / 200 \\
3\end{array}$ & $\begin{array}{l}\text { Diagnosi } \\
\mathrm{S}\end{array}$ & $\begin{array}{l}\text { Recombinant } \\
\text { polypeptides }\end{array}$ & $\begin{array}{l}\text { Louis V. } \\
\text { Kirchhoff } \\
\text { (US) / } \\
\text { Keiko Otsu } \\
\text { (JP) }\end{array}$ & $\begin{array}{l}\text { United } \\
\text { States }\end{array}$ \\
\hline
\end{tabular}

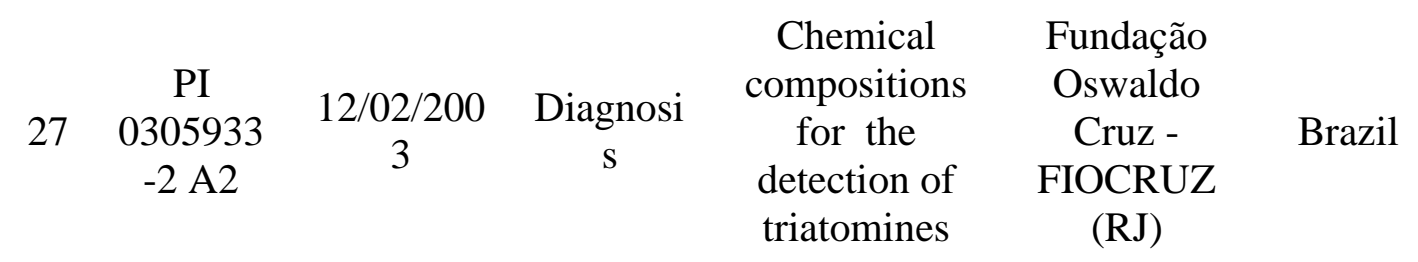

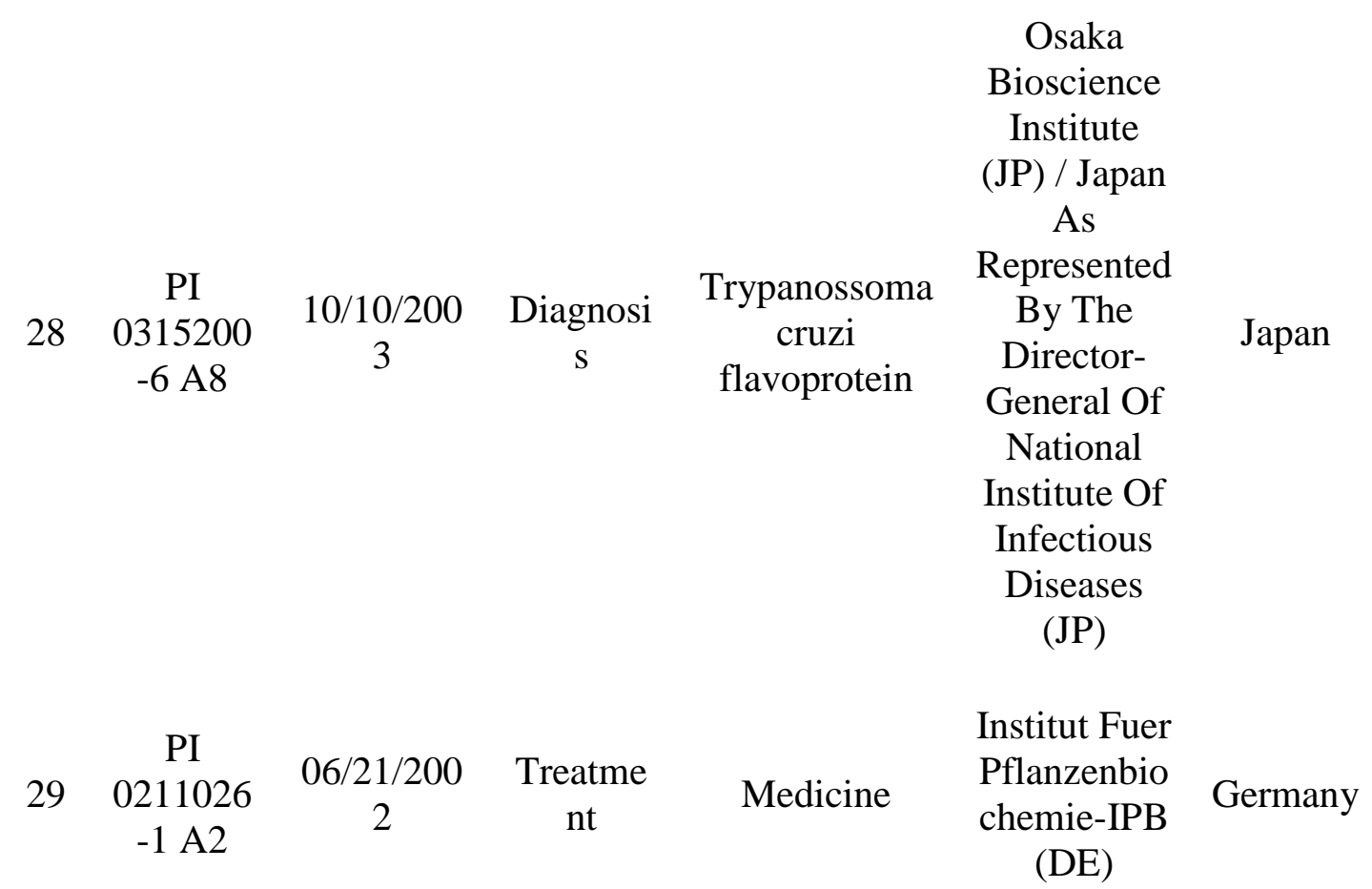




\begin{tabular}{|c|c|c|c|c|c|c|}
\hline 30 & $\begin{array}{c}\text { PI } \\
0202214 \\
-1 \mathrm{~A} 2\end{array}$ & $\begin{array}{c}06 / 05 / 200 \\
2\end{array}$ & $\begin{array}{c}\text { Diagnosi } \\
\mathrm{s}\end{array}$ & $\begin{array}{c}\text { Process of } \\
\text { immobilization } \\
\text { of antigens and } \\
\text { bio-sensors }\end{array}$ & $\begin{array}{c}\text { Fundação } \\
\text { de Amparo } \\
\text { à Pesquisa } \\
\text { do Estado } \\
\text { de São } \\
\text { Paulo - } \\
\text { FAPESP } \\
\text { (SP) }\end{array}$ & Brazil \\
\hline 31 & $\begin{array}{c}\text { PI } \\
0201237 \\
-5 \text { A8 }\end{array}$ & $\begin{array}{c}03 / 25 / 200 \\
2\end{array}$ & $\begin{array}{c}\text { Treatme } \\
\mathrm{nt}\end{array}$ & $\begin{array}{l}\text { Chemical } \\
\text { compounds }\end{array}$ & $\begin{array}{c}\text { Fundação } \\
\text { de Amparo } \\
\text { à Pesquisa } \\
\text { do Estado } \\
\text { de São } \\
\text { Paulo - } \\
\text { FAPESP } \\
\text { (SP) }\end{array}$ & Brazil \\
\hline 32 & $\begin{array}{c}\text { PI } \\
0206501 \\
-0 \text { A2 }\end{array}$ & $\begin{array}{c}01 / 17 / 200 \\
2\end{array}$ & $\begin{array}{c}\text { Treatme } \\
\mathrm{nt}\end{array}$ & $\begin{array}{c}\text { Inhibiting } \\
\text { compounds of } \\
\text { cruzipain and } \\
\text { other } \\
\text { cysteine } \\
\text { proteinases }\end{array}$ & $\begin{array}{c}\text { Amura } \\
\text { Therapeutic } \\
\text { s Limited } \\
\text { (GB) }\end{array}$ & $\begin{array}{c}\text { United } \\
\text { Kingdom }\end{array}$ \\
\hline 33 & $\begin{array}{c}\text { PI } \\
0000886 \\
-9 \text { A2 }\end{array}$ & $\begin{array}{c}01 / 13 / 200 \\
0\end{array}$ & $\begin{array}{c}\text { Diagnosi } \\
\mathrm{S}\end{array}$ & $\begin{array}{l}\text { Method of } \\
\text { disease } \\
\text { detection using } \\
\text { the ELISA } \\
\text { technique }\end{array}$ & $\begin{array}{c}\text { Fundação } \\
\text { Oswaldo } \\
\text { Cruz - } \\
\text { FIOCRUZ } \\
\text { (RJ) / } \\
\text { Fundação } \\
\text { Banco do } \\
\text { Brasil (DF) }\end{array}$ & Brazil \\
\hline
\end{tabular}

Source: Data collected by the authors directly from INPI database, 2017.

*The aforementioned deposits are not directly related to the disease in the fields of prevention, diagnosis or treatment

Notes:

(1) Exact date of data collection: 10/27/2015.

(2) Number of requests published until 10/27/2015 (RPI 2.364) that has the expression

"Chagas disease" in the abstract: 46.

The second table was elaborated, taking into account four basic structures, such as, the role of the patent, the scientific identification of the product, the inventor and the country of origin, all of them directly and randomly collected from the INPI database (2017). Basically, the theories of struggle for recognition (HONNETH, 1996) and living lawfully (BANKOWSKI, 2001) utilized for summarizing and categorizing the data in this table reveal that the institutional factor must be observed and taken into consideration to pinpoint all the necessary data and the relevant categories of data that justify this research endeavor (replicability). Moreover, the categorization of data is essential to verify whether the constitutional principle of scientific 
development in a matter of social interest is a byproduct of the patent legal system. Methodologically, the main theoretical structures of identity in law, that is, the complexity of social facts and their incorporation in the aspiration of law (parabolic reasoning) (BANKOWSKI, 2001), were the basis for extracting the role of the patent, the final product and the nature of the depositor as three main elements, which serve to determine the degree of institutional effectiveness of the constitutional principle of scientific development and social interest.

As far as Bankowski's (2001) idea of living lawfully is concerned, in the context of patent rights, related to the development of drugs for Chagas disease, there is a considerable gap between the aspiration of law and the reality of law's application both numerically and qualitatively. Numerically, there is a detectable absence of requests in this field, which would function differently if the aspiration of the patent legal system was implemented and easily expressed by a larger number of requests, at least, to file a claim to have a patent for a new drug for a neglected disease granted or not. Qualitatively, the reality of law's application indicates from the number of requests feeble commitment of scientific development to the social interest of a country where regions suffer from endemic infirmities.

The data collected, concerning Chagas disease, confirms a failure in the institutional design derived from this specific regulation involving patent rights. In fact, once there are very few requests for Chagas disease, even compared to the other neglected diseases, it is correct to ponder that the founding constitutional principle of the patent legal system is being disregarded. This means that the legal system has not been functioning as a means of incentive for new requests concerning the development of new drugs for Chagas disease. As a matter of fact, the number of requests (33) reveals that the entrance of new players in the patent system is not frequent enough to promote scientific development in a matter of social interest in Brazil. Moreover, it is necessary to clarify that this data is merely an expression of patent requests. All of them are dependent on expert analysis to be effectively granted at the end of the process of patent registration. Taking into account the theory of law as identity, the patent legal system remains in opposition to the promotion of the right to health. Institutionally, the patent legal system must be reviewed so as not to impede the exercise of the right to health, also a fundamental right in the Brazilian Constitution. It is not a matter of establishing the priority of the right to health over the right to private property, but instead the reevaluation of the patent legal system through a more careful analysis of the social conditions of certain populations and the effects of the lack of public policies in the case of neglected diseases.

This table, once elaborated, provided grounds for both the isolation and the construction of two other relevant tables (tables 3 and 4) in which two of the four basic structures were separated to evidence the appalling situation of patent requests for products concerning Chagas disease.

Table 3 - Profile of the Depositor(Jan 2001 - Oct 2015)

\begin{tabular}{cc}
\hline Nature of the Depositor & Number of registries \\
\hline NATIONAL PUBLIC & 14 \\
NATIONAL PRIVATE & 0 \\
NATIONAL PUBLIC PARTNERSHIP & 8 \\
NATIONAL PRIVATE PARTNERSHIP & 0 \\
NATIONAL PUBLIC/PRIVATE & 1 \\
PARTNERSHIP & 1 \\
INTERNATIONAL PUBLIC & 2 \\
INTERNATIONAL PRIVATE & 3 \\
INTERNATIONAL PUBLIC PARTNERSHIP & 2 \\
INTERNATIONAL PRIVATE &
\end{tabular}


INTERNATIONAL PRIVATE/PUBLIC PARTNERSHIP

Source: Data collected by the authors directly from INPI database, 2017.

Note: (1) Exact date of data collection: 10/27/2015.

Table 3 was elaborated so as to highlight the seriousness of the low number of patent requests concerning Chagas disease, confirming the commonsensical proposition that public national institutions develop the large majority of patentable products for this infirmity. In this context, it is easily detectable from the numbers above that mainly universities and governmental research agencies are the ones responsible for investing time and money in developing drugs for Chagas disease. Despite the fact that public institutions devote most of their time and money to developing new products, these new products are not going to be produced on a large scale by public institutions, which will need to either contract with or transfer to private companies their original products so that the private sector launches this specific product on the competitive market. It is not the main goal (institutional objective) of a public institution, such as, universities and public scientific agencies (FAPEMIG, FAPESP), to manufacture the product so as to provide medicine for the general population of a country. Furthermore, the majority of them have not the necessary financial and economic means to launch the product in the market.

Moreover, there are very few partnerships between private and public institutions as well as very few isolated private institutions targeting this market sector, which confirms the fact that there is little private interest in producing drugs for neglected diseases. This can be theoretically proved by the well-known economic theory that the nature of private firms is to maximize their profits, reducing transaction costs (COASE, 1993). The Brazilian Property Rights Act (BRASIL, 1996) is not achieving its constitutional principle of fostering scientific development and social innovation to promote a better quality of life for Brazilian population. There is, as a matter of fact, a structural failure in the patent legal system insofar as the ideal of the law is not been effectively fulfilled in the process of law in action. Institutionally, this table evidences the minimal effectiveness of the property rights constitutional principle, taking into account that, as the private market is not interested in producing drugs for Chagas disease, it is logically deducible that the population in endemic regions of Brazil are lacking an essential element of Honneth's (1996) theory, such as, social esteem. The absence of social esteem produces a break in the virtuous circle of recognition, which, basically, jeopardizes the other two elements of the circle, love and respect (HONNETH, 1996). The fact that a specific right is granted to a person, such as access to health care, is not enough if collateral rights are not equally attributed to that person. Access to health care, to be effective, demands not only investment in research for new drugs, but also the mass production of these drugs in order to provide cheaper final products for final consumers. In this context, it is relevant to pinpoint that patent rights assume a collateral function in the system of rights, for they can be seen as an instrument for providing the essential means and the stimuli for innovation and scientific development as the fundamental basis for health care rights, such as, access to essential medicines. The collected data above reveals that the capacity to create new medicines, though reduced, is not the major problem faced by the Brazilian health system, insofar as much more, beyond the registry of a patent request concerning Chagas disease, is needed, which is a final product launched on the competitive market. According to the annual report from Drugs For Neglected Diseases initiative (DNDi, 2013) ${ }^{5}$, eight million people suffer from Chagas disease, whereas less than $1 \%$ receives proper treatment. These specific statistics serve to corroborate the ineffectiveness of the system of patent rights,

\footnotetext{
${ }^{5}$ Feres, Silva and Moreira (2015) analyze the advocacy of DNDi in the context of researching, developing and delivering affordable drugs for neglected diseases, specifically, considering its intellectual property policy, available at DNDi's official website: http://www.dndi.org/advocacy/ip/ (DNDi, 2017).
}

Revista de Direito Brasileira | São Paulo, SP | v. 20 | n. 8 | p. 81-103 |Mai./Ar. 2018 
which do not comply with the constitutional principle of scientific development and social interest, extracted from the fundamental rights and constitutional guarantees in the Brazilian Constitution. Cross-referencing both data sources reinforces the basic inference that the entrance of new private players in the patent system is not sufficient to promote scientific development in a matter of social interest in Brazil, for this endeavor is not within the basic nature of a private firm.

Table 4 - Functional Profile of the Registries of Patent Requests (Jan 2001 - Oct 2015)

\begin{tabular}{cc}
\hline Role & Number of Registries \\
\hline PREVENTION & 3 \\
DIAGONOSIS & 9 \\
TREATMENT & 14 \\
PREVENTION AND/OR & 1 \\
DIAGNOSIS & \\
PREVENTION AND/OR & 5 \\
TREATMENT & 0 \\
DIAGNOSIS AND/OR TREATMENT & 0 \\
PREVENTION, DIAGNOSIS & 1 \\
AND/OR TREATMENT & 1 \\
ANOMOLOUS REGISTRIES*
\end{tabular}

Source: Data collected by the authors directly from INPI database, 2017.

*Registries, which cannot be classified as prevention, diagnosis and treatment.

Note: (1) Exact date of data collection: 10/27/2015.

Table 4 was partially extracted from the larger table aforementioned (table 2). It is essential to consider that most of the requests registered in the INPI database (2017) are concentrated on the treatment of Chagas disease. If the data is analyzed in isolation from the juridical and political factors, it will reveal a positive side of the incentive aspired to by the patent legal system. However, it is methodologically accurate to take into account the fact that medicines and any sort of drugs must be produced on a large scale in order to reach the general population in need of treatment. Going back to the 2013 DNDi annual report (DNDi, 2013), it can be concluded that very little has been done to produce medicines for Chagas disease on a large scale on the competitive pharmaceutical market. From cross-referencing the available data sources, it is deducible that the patent legal system is ineffective to subsume the complexity of real facts in the universal and abstract perspective of the intellectual property rights Act, as Bankowski (2001) advocates in his "living lawfully theory". Identity in law, as the underpinnings of this research, demonstrates that, if the original goal of the existing patent legal system were human welfare (social interest interwoven with scientific development), investigation concerning the complex relation among prevention, diagnosis and treatment of Chagas disease would be far more frequent than it is shown in table 4 below. The pharmaceutical private market has, indeed, its own needs and goals, as can be substantiated by the nature of private firms (COASE, 1993). However, legislation and public policy must not be manipulated in order to fulfill the private market's agenda. The categorization of the data concerning the prevention, the diagnosis and the treatment of Chagas disease illustrates the aggravating situation of this malady. Even if all those requests were to be approved by the INPI experts and the public institutions were able to produce those products on a large scale, the thirty-three requests do not represent the totality of possible drugs for the treatment of Chagas disease, for they are divided into three diverse categories. Thus, the ongoing problem of research, development and delivering of affordable drugs for neglected diseases is clearly posited.

Revista de Direito Brasileira | São Paulo, SP | v. 20 | n. 8 | p. 81-103 |Mai./Ago. 2018 


\section{CONCLUSION}

This paper is part of a broader research project, which continues to analyze different aspects of the patent legal system concerning the registering of products for prevention, diagnosis and treatment of neglected diseases.

Nonetheless, it is important to emphasize that the results here achieved reveal a problematic perspective of the Brazilian patent legal system. In fact, it confirms a tendency of the non-fulfillment of the principle of scientific development and social interest, set out in the Brazilian Constitution. Moreover, this constitutional principle should not be based on the idea of mere economic growth as well as mere quantitative aspects of patent requests at INPI. Law as identity plays a relevant role in the process of analyzing the patent legal system, inasmuch as to extract, to summarize and to categorize the valid and specific data concerning patent requests from the INPI database, thus revealing any contradictions and negative conditions affecting the development of products for neglected diseases.

After listing at table 1 all the patent requests, referring to dengue, Chagas disease, leishmaniasis and malaria, Chagas disease had the lowest level of request registrations during the period of analysis. During this time, only 33 patents for Chagas disease were requested, which corroborates the hierarchy among different sorts of neglected diseases. To sum up, some diseases are more neglected than others. Once this heterogeneity of requests is verified, the patent legal system must be reinterpreted in order to consider the complexity of each disease in its specific context.

Therefore, according to table 2, the number of requests (33) leads to the descriptive inference that the entrance of new players in the patent system is not frequent enough to promote scientific development in a matter of social interest in Brazil.

Table 3 highlights the impact of the low number of patent requests concerning Chagas disease, confirming the proposition that mainly universities and governmental research agencies are the ones responsible for investing time and money in developing drugs for this infirmity. In addition, there are very few partnerships between private and public institutions as well as very few investments from private institutions alone in this specific market. Finally, the entrance of new private players in the patent system is not sufficient to promote scientific development in a matter of social interest in Brazil, for this endeavor is not within the basic nature of a private firm.

Table 4 depicts the categorization of the data concerning the prevention, the diagnosis and the treatment of Chagas disease. Even if all those deposits were to be approved by the INPI experts and the public institutions were able to produce those products on a large scale, the thirtythree requests do not represent the totality of possible drugs for the treatment of Chagas disease, for they are divided into three diverse categories.

Finally, the agonizing problem of research, development and delivering of affordable drugs for neglected diseases is clearly stated and needs to be faced by Brazilian authorities responsible for implementing as well as reinterpreting the patent legal system, taking into account the constitutional principle of scientific development based on social interest.

\section{REFERENCES}

ACADEMIA BRASILEIRA DE CIÊNCIAS (ABC) (Rio de Janeiro) (Org.). Doenças Negligenciadas. Rio de Janeiro: Academia Brasileira de Ciências, 2010. 43 p. Coordenação Wanderley de Souza. Available at: <http://www.abc.org.br/IMG/pdf/doc-199.pdf>. Access on: 20 out. 2016 
BANKOWSKI, Zenon. Living lawfully: love in law and law in love. Dordrecht: Kluwer Academic Publishers, 2001.

BOLDRIN, Michele; LEVINE, David K..Against Intellectual Monopoly. Cambridge: Cambridge University Press, 2008. 312 p. Available at: <http://levine.sscnet.ucla.edu/papers/anew.all.pdf $>$. Access on: 10 dez. 2016.

BOLDRIN, Michele; LEVINE, David K. The Case Against Patents. Journal Of Economic Perspectives, [s.1.], v. 27, n. 1, p.3-22, fev. 2013. American Economic Association. http://dx.depsoi.org/10.1257/jep.27.1.3. Available

at: <https://www.aeaweb.org/articles?id=10.1257/jep.27.1.3>. Access on: 10 dez. 2016.

BRASIL. Constituição (1988). Constituição da República Federativa do Brasil. Brasília, DF: Senado Federal, 05 out. $1988 . \quad$ Available at: <http://www.planalto.gov.br/ccivil_03/constituicao/constituicaocompilado.htm>. Access on: 01 mar. 2017

BRASIL. Lei no 9279, de 14 de maio de 1996. Regula direitos e obrigações relativos à propriedade industrial.. Lei da Propriedade Industrial. Brasília, DF, Available at: <http://www.planalto.gov.br/ccivil_03/leis/L9279.htm>. Access on: 07 mar. 2017.

COASE, Ronald. The nature of the firm.in WILLIAMSON, Oliver \& WINTER, Sidney G.(ed.) The nature of the firm: origins, evolution and development. $2^{\mathrm{a}}$ ed. New York : Oxford university press, 1993.

CORREA, Carlos M. Trade Related Aspects of Intelectual Property Rights: a comentary on the TRIPS agreement. Estados Unidos da América: Oxford University Press, 2007. 573 p.

DRUGS FOR NEGLECTED DISEASES INITIATIVE (DNDI). Annual Report DNDi Latin America 2012-2013. Geneva: Dndi, 2013. Available at: <http://www.dndi.org/wpcontent/uploads/2009/03/DNDi_AR_2013_1.pdf>. Access on: 20 mar. 2015

DRUGS FOR NEGLECTED DISEASES INITIATIVE. Intellectual Property. 2017. Available at: <http://www.dndi.org/advocacy/ip/>. Access on: 07 mar. 2017.

DWORKIN, Ronald. Law’s Empire, Oxford: Hart Publishing Press, 1986.

EPSTEIN, Lee; KING, Gary. Rules of inference. The University Of Chicago Law Review, Chicago, v. 69, n. 1, p.1-133, winter. 2002. Available at: <http://gking.harvard.edu/files/rules.pdf>. Access on: 06 mar. 2017.

FERES, Marcos Vinício Chein. Law as Integrity and Law as Identity: Legal Reasoning, State Intervention, and Public Policies. German Law Journal, v. 14, p. 1147-1162, 2013.

FERES, Marcos Vinício Chein; SILVA, Alan Rossi. A ASPIRAÇÃO DO SISTEMA DE PATENTES E O CASO DOS PRODUTOS TERAPÊUTICOS PARA DOENÇAS NEGLIGENCIADAS. Rei - Revista Estudos Institucionais, [s.1.], v. 2, n. 2, p.756-798, 1 fev. 2017. Revista Estudos Institucionais. http://dx.doi.org/10.21783/rei.v2i2.60. Available at: <https://www.estudosinstitucionais.com/REI/article/view/60/115>. Access on: 06 mar. 2017. 
FERES, Marcos Vinício Chein; SILVA, Alan Rossi; MOREIRA, Thaís Miranda. A DNDi E A POLÍTICA DE PROPRIEDADE INTELECTUAL: A ZONA INTERMEDIÁRIA DA LEGALIDADE. In: II SEMINÁRIO INTERNACIONAL DE DIREITOS HUMANOS E EMPRESAS, 2., 2015, Juiz de Fora. Anais... . Juiz de Fora: Editora UFJF, 2015. p. 1 - 18. Available at: $<$ https://seminariosinternacionaisdireitoshumanoseempresas.files.wordpress.com/2015/10/artigocompleto-grupo-de-trabalho-ii-a-dndi-e-a-polc3adtica-de-propriedade-intelectual-a-zonaintermedic3a1ria-da-legalidade.pdf>. Access on: 10 dez. 2016.

GOLD, E. Richard et al. Are Patents Impeding Medical Care and Innovation? Plos Med, [s.1.], v. 7, n. 1, p.1-5, 5 jan. 2010. Public Library of Science (PLoS). http://dx.doi.org/10.1371/journal.pmed.1000208. Available at: <http://journals.plos.org/plosmedicine/article?id=10.1371/journal.pmed.1000208>. Access on: 29 mar. 2016

HONNETH, Axel. The struggle for recognition: the moral grammar of social conflicts. Cambridge: Polity Press, 1996. Translated by Joel Anderson.

INSTITUTO NACIONAL DA PROPRIEDADE INDUSTRIAL (INPI). Instituto Nacional da Propriedade Industrial (INPI). Available at: <http://www.inpi.gov.br/>. Access on: 06 mar. 2017.

LINDOSO, José Angelo L.; LINDOSO, Ana Angélica B. P.. Neglected tropical diseases in Brazil. Rev. Inst. Med. Trop. S. Paulo, São Paulo, v. 51, n. 5, p.247-253, out. 2009. Available at: $<$ http://www.scielo.br/scielo.php?script=sci_arttext\&pid=S0036-

46652009000500003\&lng=en\&nrm=iso>. Access on: 06 mar. 2017.

MÉDECINS SANS FRONTIÈRES (MSF) (Geneva). Lives On The Edge: Time To Align Medical Research And Development With People's Health Needs. Geneva: Médecins Sans Frontières (MSF), 2016. 52 p. Available at: <http://www.msfaccess.org/content/report-livesedge-time-align-medical-research-and-development-people's-health-needs $>$. Access on: 21 out. 2016.

ORGANIZAÇÃO MUNDIAL DA SAÚDE (OMS). Primeiro relatório da OMS sobre doenças tropicais negligenciadas: Avanços para superar o impacto global de doenças tropicais negligenciadas. Brasil: Organização Mundial da Saúde (OMS), 2010. 172 p.

PEDRIQUE, Belen et al. The drug and vaccine landscape for neglected diseases (2000-11): a systematic assessment. The Lancet Global Health, [s.1.], v. 1, n. 6, p.371-379, dez. 2013. Elsevier BV. http://dx.doi.org/10.1016/s2214-109x(13)70078-0. Available at: <http://www.thelancet.com/journals/langlo/article/PIIS2214-109X(13)70078-0/abstract>. Access on: 27 abr. 2016

TAYLOR, Charles. Sources of the self: the making of the modern identity, Cambridge: Harvard University Press, 1989.

WORLD HEALTH ORGANIZATION. Neglected tropical diseases. 2017. Available at: <http://www.who.int/neglected_diseases/diseases/en/>. Access on: 06 mar. 2017. 
WORLD TRADE ORGANIZATION (WTO). Trade-related aspects of intellectual property rights. Available at: <https://www.wto.org/english/docs_e/legal_e/27-trips_01_e.htm>. Access on: 06 mar. 2017.

This paper has the financial support of FAPEMIG (Fundação de Amparo à Pesquisa de Minas Gerais) and CNPq (Conselho Nacional de Desenvolvimento Científico e Tecnológico). 